\title{
Caring for a Child with Hypoplastic Left Heart Syndrome: Parent and Medical Perspective
}

Benjamin Nicholas · Christina Nicholas · Robin L. Allen •

Clifford L. Cua (D)

Received: November 2, 2021 / Published online: November 26, 2021

(c) The Author(s) 2021

\section{ABSTRACT}

This article, co-authored by parents of a child with hypoplastic left heart syndrome (HLHS) and his pediatric cardiology care team, discusses the parents' experience of having a child with HLHS from diagnosis through living day-to-day with the heart condition as well as future directions.

Keywords: Parents; Congenital heart disease; Hypoplastic left heart syndrome

\section{Key Summary Points}

Hypoplastic left heart syndrome (HLHS) is one of the most severe congenital heart defects with an estimated incidence of $0.16-0.36$ per 1000 live births.

Children with HLHS will require at least three operative procedures with likely even more cardiac interventions throughout their lifetime.

Even when there are minimal procedural morbidities, parents/caregivers still have ongoing anxiety concerning the future health and welfare of their child because of a paucity of long-term data.

Future research endeavors should focus on maximizing neurological and psychological outcomes for these children and families.
B. Nicholas · C. Nicholas

Patient Author, Columbus, OH, USA

B. Nicholas · C. Nicholas · R. L. Allen ·

C. L. Cua $(\square)$

Heart Center, Nationwide Children's Hospital, Columbus, $\mathrm{OH}, \mathrm{USA}$

e-mail: clcua@hotmail.com

\section{PARENT PERSPECTIVE}

The challenges parents face when a child is born with a chronic health condition can be wideranging. For my wife and I, these challenges began when our son was diagnosed prenatally, at 20 weeks, with hypoplastic left heart 
syndrome (HLHS). HLHS is one of the most severe forms of all congenital heart defects (CHD). A CHD diagnosis was not only shocking but unexpected as our oldest son was a healthy, happy 3-year-old at the time. We were left with feelings of devastation and anger but most of all we were terrified.

We soon decided that, while normal to feel so many emotions, we needed to focus our attention on education so we could make the best possible decisions for our son. With the help of our son's cardiologist, cardiothoracic surgeon, and many members of their respective teams we immersed ourselves in HLHS education. Before the diagnosis, neither of us had heard of HLHS. HLHS was and is still frightening for us because, as we soon learned, all the existing medical interventions for HLHS are relatively new.

After much research, thought, and prayer we chose staged palliation for our son. On his sixth day of life, he underwent his first open-heart procedure, the hybrid approach [1]. We elected the hybrid procedure, a relatively novel option, for his first surgery in lieu of the traditional Norwood procedure. The hybrid approach is a far less invasive option; we made this decision with the desire of delaying the major surgical stage to later in life.

Our son recovered well from the hybrid operation and progressed well during the interstage period. Six months later he underwent a bidirectional Glenn operation. Our son continued to thrive and was met with little difficulty. He was scheduled to undergo his Fontan operation, the final procedure in the staged palliation, in the spring of 2020. Unfortunately, this fell within the onset of the COVID-19 pandemic when so much was still unknown. After speaking with our son's cardiologist and cardiothoracic surgeon we decided to delay the Fontan procedure until the summer of 2021. After a 1-year delay our son completed the Fontan procedure in July 2021. All aspects of the staged palliation were a remarkable success and our son, who is now almost 4 , is flourishing.

Now that all surgical procedures have been completed our son only visits his cardiologist once every 6 months to a year. We are where we have always dreamed of being, but we have been left with a feeling of nervous independence. While we have been blessed with an outcome greater than we ever imagined there are times when we find ourselves asking "what is next?" As was stated earlier, the existing medical interventions for HLHS are relatively new, and with that comes a whole new group of children and adults who are living with these congenital heart defects.

With our son's Fontan complete, my wife and I have now moved to educate ourselves on what the future will hold for our son. What are the areas of concern as he continues to grow? What can we do to support his health and happiness in all aspects of life? What advancements in the care of patients with HLHS are being developed and researched and what advancements are possible in the future?

\section{MEDICAL PERSPECTIVE}

HLHS is one of the most severe forms of CHD with an estimated incidence of $0.16-0.36$ per 1000 live births [2]. Current management options for children born with HLHS include surgical palliation, primary transplantation, or hospice care [3]. From a general standpoint, surgical palliation is usually the most common pathway chosen by the caregivers. There are currently three surgical palliative strategies (Norwood procedure with Blalock-Taussig shunt, Norwood procedure with right ventricle to pulmonary artery conduit, or hybrid procedure) with the two variations of the Norwood procedure being the most prevalent surgical strategies performed in the USA [4]. Regardless of surgical pathway chosen, these children require a minimum of three operative procedures with a high probability of multiple cardiac procedures throughout their lifetime.

When the Norwood pathway was first described in the early 1980s for children with HLHS, mortality was reported to be roughly $70 \%$ by 1 year of age [5], but with improvements in preoperative, operative, and postoperative care, mortality has significantly decreased with survival to 1 year of age now approximately $70 \%$ [6]. As mortality has decreased for these children, they are now 
becoming adolescents and adults [7]. Decreasing mortality will always be a major goal for these children, but decreasing mid- and longterm morbidities has also started to come into focus as a major goal for this population.

As stated by the parental question "What is next?", the future is always in flux, but major areas of likely research will deal with improving neurodevelopmental and psychosocial outcomes in patients and families dealing with HLHS. Patients with HLHS are known to have cognitive and developmental impairments compared to age-matched peers. Current guidelines recommend early screening and intervention to maximize developmental outcomes [8]. Future studies will need to determine the extent of benefits of these early interventions. In addition, the effects of CHD, especially HLHS, are not only felt by the patient with CHD but the entire family unit [9-12]. Future studies will need to determine how to best support not only the patient with HLHS but also those around the patient dealing with the lifelong impact of this diagnosis.

Thankfully, for this family, their child has not experienced significant morbidities and the hope is that this will continue. Looking back at the initial outcomes for these patients to where we are now is truly remarkable. It is only via the partnership between families and the medical field that progress will continue to be made to improve outcomes in this complicated patient population.

\section{ACKNOWLEDGEMENTS}

Funding. No funding or sponsorship was received for the publication of this article.

Authorship. All named authors meet the International Committee of Medical Journal Editors (ICMJE) criteria for authorship for this article, take responsibility for the integrity of the work as a whole, and have given their approval for this version to be published.
Disclosures. Benjamin Nicholas, Christina Nicholas, Robin L Allen and Clifford L Cua have nothing to disclose.

Compliance with Ethics Guidelines. This article does not contain any new studies with human participants or animals performed by any of the authors.

Peer Review. Please note, contrary to the journal's standard double-blind peer review process, as a commentary this article underwent review by a member of the journal's Editorial Board.

Open Access. This article is licensed under a Creative Commons Attribution-NonCommercial 4.0 International License, which permits any non-commercial use, sharing, adaptation, distribution and reproduction in any medium or format, as long as you give appropriate credit to the original author(s) and the source, provide a link to the Creative Commons licence, and indicate if changes were made. The images or other third party material in this article are included in the article's Creative Commons licence, unless indicated otherwise in a credit line to the material. If material is not included in the article's Creative Commons licence and your intended use is not permitted by statutory regulation or exceeds the permitted use, you will need to obtain permission directly from the copyright holder. To view a copy of this licence, visit http://creativecommons.org/licenses/by$\mathrm{nc} / 4.0 /$.

\section{REFERENCES}

1. Galantowicz M, Cheatham JP, Phillips A, et al. Hybrid approach for hypoplastic left heart syndrome: intermediate results after the learning curve. Ann Thorac Surg. 2008;85:2063-70 (discussion 2070-1).

2. Brownell LG, Shokeir MH. Inheritance of hypoplastic left heart syndrome (HLHS): further observations. Clin Genet. 1976;9:245-9.

3. Yates AR, Hoffman TM, Boettner B, Feltes TF, Cua CL. Initial counseling prior to palliation for 
hypoplastic left heart syndrome. Congenit Heart Dis. 2011;6:347-58.

4. Wilder TJ, McCrindle BW, Hickey EJ, et al. Is a hybrid strategy a lower-risk alternative to stage 1 Norwood operation? J Thorac Cardiovasc Surg. 2017;153:163-172 e6.

5. Norwood WI, Lang P, Casteneda AR, Campbell DN. Experience with operations for hypoplastic left heart syndrome. J Thorac Cardiovasc Surg. 1981;82: 511-9.

6. Ohye RG, Sleeper LA, Mahony L, et al. Comparison of shunt types in the Norwood procedure for singleventricle lesions. N Engl J Med. 2010;362:1980-92.

7. Gilboa SM, Devine OJ, Kucik JE, et al. Congenital heart defects in the United States: estimating the magnitude of the affected population in 2010 . Circulation. 2016;134:101-9.

8. Marino BS, Lipkin PH, Newburger JW, et al. Neurodevelopmental outcomes in children with congenital heart disease: evaluation and management: a scientific statement from the American Heart Association. Circulation. 2012;126:1143-72.

9. Caris EC, Dempster N, Wernovsky G, et al. Anxiety scores in caregivers of children with hypoplastic left heart syndrome. Congenit Heart Dis. 2016;11: 727-32.

10. Caris EC, Dempster N, Wernovsky G, et al. Perception scores of siblings and parents of children with hypoplastic left heart syndrome. Congenit Heart Dis. 2018;13:528-32.

11. Golfenshtein N, Hanlon AL, Deatrick JA, MedoffCooper B. Parenting stress in parents of infants with congenital heart disease and parents of healthy infants: the first year of life. Compr Child Adolesc Nurs. 2017;40:294-314.

12. Davis CC, Brown RT, Bakeman R, Campbell R. Psychological adaptation and adjustment of mothers of children with congenital heart disease: stress, coping, and family functioning. J Pediatr Psychol. 1998;23:219-28. 